\title{
PERAN TANAMAN BENGKUANG (Pachyrrhizuz erosus L.) DALAM MENDUKUNG SISTEM PERTANIAN ORGANIK
}

\author{
Robiatul Adawiyah ${ }^{\left.{ }^{*}\right)}$ dan Terry Pakki ${ }^{2)}$ \\ ${ }^{1)}$ Dosen Agroteknologi, ${ }^{2)}$ Dosen Proteksi Tanaman, Fakultas Pertanian, Universitas Halu Oleo \\ ${ }^{1 *}$ Corresponding email : robiatulada1@gmail.com
}

\begin{abstract}
Abstrak
Tantangan pertanian ke depan adalah peningkatan produksi pertanian, kelestarian lingkungan dan kesehatan masyarakat sebagai akibat meningkatnya jumlah penduduk dan kesadaran masyarakat akan pengaruh negatif yang ditimbulkan oleh penggunaan pupuk anorganik dan pestisida sintetik/kimia (anorganik). Sistem pertanian organik merupakan salah satu solusi yang diajukan untuk diterapkan pada sistem pertanian di masa yang akan datang. Sistem pertanian organik adalah sistem budidaya pertanian yang mengandalkan bahan-bahan alami tanpa menggunakan bahan kimia/sintetis (anorganik). Pemanfaatan pupuk organik dan pestisida nabati dalam usaha pertanian akan mengurangi resiko pencemaran lingkungan, meningkatkan efisiensi pemupukan, serta menekan pengaruh negatif dari penggunaan pupuk anorganik dan pestisida sintesik/kimia (anorganik). Prinsip dalam sistem pertanian organik adalah adanya keseimbangan siklus hara dan kesuburan tanah serta pengendalian hama dan penyakit secara terpadu. Untuk meningkatkan kesuburan tanah dan memenuhi kebutuhan pupuk organik di dalam menjaga keseimbangan siklus hara, serta mengurangi penggunaan pestisida nabati, peran legum seperti bengkuang (Pachyrrhizuz erosus L.) perlu dikaji lebih mendalam. Tanaman bengkuang sangat potensial dalam mendukung diterapkannya sistem pertanian organik karena; biomassa yang banyak dan mengandung nitrogen yang tinggi $(3.42 \%-3.51 \%)$, kemampuan hidup yang sangat luas di berbagai kondisi lahan karena bersimbiosis dengan bakteri Rhizobium dan Bradyrhizobium dalam menambat nitrogen $\left(\mathrm{N}_{2}\right)$ udara dan bersimbiosis dengan cendawan mikoriza (AMF) yang dapat membantu penyerapan unsur hara terutama fosfor. Selain itu, kecuali umbi, bagian tanaman lainnya terutama pada biji bengkuang mengandung metabolit sekunder seperti rotenon yang bersifat insektisida. Dengan demikian maka bengkuang ini dapat dimanfaatkan sebagai bahan pupuk organik dan sebagai insektisida nabati dalam mendukung sistem pertanian organik.
\end{abstract}

Kata Kunci: bengkuang(Pachyrrhizuz erosus L.), legum, rotenon, sistem pertanian organik

\begin{abstract}
The challenge of agriculture in the future is to increase agricultural production, environmental sustainability and public health as a result of increasing population and public awareness of the negative effects caused by the use of inorganic fertilizers and chemical/ synthetic pesticides. Organic farming system is one of the solutions proposed to be applied to agricultural systems in the future. Organic farming system is an agricultural cultivation system that relies on natural materials without using synthetic/chemicals (inorganic). Utilization of organic fertilizers and pesticides in agricultural businesses will reduce the risk of environmental pollution, improve fertilization efficiency, and reduce the negative effects of the use of inorganic fertilizers and chemical/synthetic pesticides. The principle in organic farming systems is the balance of nutrient cycling and soil fertility and integrated pest and disease control. To improve soil fertility and meet the needs of organic fertilizer in maintaining the balance of nutrient cycles, and reduce the use of synthetic chemical pesticides, the role of legumes such as yam bean (Pachyrrhizuz erosus L.) needs to be studied more deeply. Yam bean plants are very potential in supporting the implementation of organic farming systems because; a lot of high and nitrogen containing biomass $(3.42 \%-3.51 \%)$, a very broad life ability in various land conditions because it is symbiotic with Rhizobium and Bradyrhizobium bacteria in fixing nitrogen (N2) air and symbiosis with mycorrhizal fungi (AMF) which can help absorption of nutrients, especially phosphorus. Especially in jicama seeds contain secondary metabolites such as rotenone which are insecticides. Thus, this yam bean can be used as an organic fertilizer and as a organic/vegetable insecticide in supporting organic farming systems.
\end{abstract}

Keywords: Yam bean (Pachyrrhizuz erosus L.), legumes, rotenon, organic farming systems 


\section{PENDAHULUAN}

Dalam memenuhi kebutuhan pangan bagi penduduk Indonesia, pertanian dihadapkan pada berbagai tantangan. Tantangan tersebut tidak hanya tertumpu pada upaya peningkatan produksi pertanian, tetapi juga pada kelestarian lingkungan dan kesehatan masyarakat. Teknologi produksi yang dimasyarakatkan dan dilaksanakan oleh petani cenderung sangat boros energi dan berpengaruh negatif terhadap kelestarian kesuburan tanah, tanaman, manusia dan lingkungan. Hal ini sebagai akibat dari ketergantungan petani pada penggunaan pupuk anorganik dan pestisida sintetik/kimia (anorganik).

Pemanfaatan pupuk organik untuk usaha pertanian akan mengurangi resiko pencemaran lingkungan, meningkatkan efisiensi pemupukan, serta menekan pengaruh negatif dari penggunaan pupuk anorganik. Hal ini berarti bahwa dengan pemanfaatan bahan organik akan mendukung program pertanian organik yang berkelanjutan dan berwawasan lingkungan. Sistem pertanian berkelanjutan dapat tercapai bila sistem tersebut secara ekologi tidak merusak, secara ekonomi menguntungkan dan secara sosial dapat diterima, sehingga secara teknologi, ekologi, ekonomi, dan sosial dapat berkelanjutan. Dengan demikian diharapkan kelestarian sumber daya pertanian dapat dipertahankan dan kontaminasi terhadap lingkungan hidup dan pengaruh negatif lainnya terhadap unsur ekosistem yang lain dapat diupayakan seminimal mungkin. Prinsip dalam sistem pertanian berkelanjutan adalah adanya keseimbangan siklus hara dan kesuburan tanah serta pengendalian hama dan penyakit secara terpadu.

Perlu dikaji lebih mendalam terkait peran tanaman legum seperti bengkuang (Pachyrrhizuz erosus L.) untuk meningkatkan kesuburan tanah dan memenuhi kebutuhan pupuk organik di dalam menjaga keseimbangan siklus hara, serta mengurangi penggunaan pestisida sintatik/kimia. Namun di Indonesia penanaman bengkuang baru dilakukan secara tradisional dan penelitian tentang bengkuang juga masih terbatas. Padahal melihat potensi yang begitu tinggi, biomassa yang banyak dan mengandung nitrogen yang tinggi, kemampuan hidup yang sangat luas di berbagai kondisi lahan, dan keanekaragaman bengkuang yang banyak, dan menghasilkan metabolit sekunder seperti rotenon yang bersifat insektisida maka tidak mustahil bengkuang ini dapat dimanfaatkan sebagai bahan pupuk organik dan sebagai pestisida nabati terutama untuk pengendali hama.

Berdasarkan hal tersebut di atas maka peran bengkuang sebagai komponen penting dalam sistem pertanian organik yang berkelanjutan dalam kaitannya dengan biomassa yang banyak, mengandung nitrogen yang tinggi dan 
memiliki sifat insektisida perlu dipelajari lebih mendalam.

\section{Karakteristik Tanaman Bengkuang ( $P$. erosus L.)}

$$
\text { Bengkuang }(P \text {. erosus L. = yam }
$$

bean) merupakan tanaman asli dari Amerika Tengah dan ditanam menggunakan benih. Di Asia, bengkuang pertama kali diperkenalkan di Negara Filipina dan negara-negara lain di kawasan Asia Tenggara (Lingga, 2010). Bengkuang merupakan buah yang kaya akan berbagai zat gizi yang sangat penting untuk kesehatan terutama vitamin dan mineral. Pada penelitian yang dilakukan oleh Lukitaningsih (2009), menunjukkan bahwa bengkuang mengandung vitamin $\mathrm{C}$, flavonoid, dan saponin yang merupakan tabir surya alami untuk mencegah kulit rusak oleh radikal bebas.

Tanaman bengkuang ( $P$. erosus) dikenal baik oleh masyarakat Indonesia. Umbi tanaman bengkuang biasa dimanfaatkan sebagai buah atau bagian dari beberapa jenis makanan seperti rujak, asinan atau dimakan segar. Umbi bengkuang mengandung agen pemutih (whitening agent) yang dapat memutihkan dan menghilangkan tanda hitam dan pigmentasi di kulit. Bengkuang mengandung vitamin $C$ dan senyawa fenol yang dapat berfungsi sebagai sumber antioksidan bagi tubuh (Assaori, 2010).

Hasil analisis menunjukkan bahwa dalam $100 \mathrm{~g}$ umbi segar bengkuang ( $P$. erosus) memiliki kandungan air sebesar $78 \%$ - 94\%, 2,1 g - 10,7 g pati, $1 \mathrm{~g}-2,2$ g protein, $0,1 \mathrm{~g}-0,8 \mathrm{~g}$ lemak, $14 \mathrm{~g}-21 \mathrm{~g}$ vitamin $\mathrm{C}$, dan 22 kalori - 58 kalori energi (de Melo et al., 1994; Sorensen, 1998). Berdasarkan asumsi bahwa rata-rata hasil 35 ton ha $^{-1}$, bobot kering berkisar $6 \%-$ $22 \%$, kandungan pati $50 \%$ bahan kering dan protein $10 \%$, maka kandungan pati dan protein yang dihasilkan oleh bengkuang per hektarnya mencapai 1,05 ton $-3,85$ ton pati dan 0,21 ton $-0,77$ ton protein. Fakta ini mengindikasikan bahwa bengkuang sebenarnya merupakan sumber pati dan protein yang cukup potensial. Oleh karena itu, industri tepung kaya protein berbasis bengkuang sangat memungkinkan untuk dikembangkan. Kandungan gizi bengkuang disajikan pada Tabel 1.

Bengkuang memiliki komposisi yang bervariasi sesuai dengan jenis kultivar dan kematangan bagian tanaman. Pada bentuk umbi siap panen, bengkuang mengandung $80-90 \%$ air, $10-17 \%$ karbohidrat, $1-2,5 \%$ protein, $0,5-1 \%$ serat, $0,1-0,2 \%$ lemak dan vitamin $\mathrm{C}$. Pada buah muda bengkuang mengandung $86 \%$ air, 10\% karbohidrat, $2,6 \%$ protein, $0,9 \%$ serat, $0,3 \%$ lemak dan vitamin C. Pada bentuk benih yang sudah matang, mengandung 30\% minyak/lemak, pachyrrizon, asam pachyrrizon, 0,5 - 1\% rotenon dan 0,5 - $1 \%$ rotenoid. Pada bagian daun bengkuang mengandung kurang dari $0,01 \%$ rotenon dan rotenoid, 
tetapi pada bagian umbi tidak memiliki senyawa ini (Chooi, 2008).

Tabel 1. Hasil analisis kandungan gizi dalam $100 \mathrm{~g}$ bengkuang segar.

\begin{tabular}{lll}
\hline \multirow{2}{*}{ Jenis Gizi } & \multicolumn{2}{c}{ Jumlah Kandungan Gizi } \\
\cline { 2 - 3 } & $\begin{array}{c}\text { Wirakusumah } \\
(2004)\end{array}$ & $\begin{array}{c}\text { Sorensen } \\
(1996)\end{array}$ \\
\hline Vitamin B1 & $0,04 \mathrm{mg}$ & \\
\hline Vitamin C & $20,0 \mathrm{mg}$ & $14-21 \mathrm{gram}$ \\
\hline Energi & $55,0 \mathrm{kal}$ & $22-58 \mathrm{kalori}$ \\
\hline Karbohidrat & $12,8 \mathrm{~g}$ & \\
\hline Lemak & $0,2 \mathrm{~g}$ & $0.1-0.8 \mathrm{~g}$ \\
\hline Protein & $1,4 \mathrm{~g}$ & $1-2.2 \mathrm{~g}$ \\
\hline Zat Besi & $1,0 \mathrm{mg}$ & \\
\hline Kalsium & $15,0 \mathrm{mg}$ & \\
\hline Fosfor & $18,0 \mathrm{mg}$ & \\
\hline Pati & & $2.1-10.7 \mathrm{~g}$ \\
\hline Kadar Air & $86-90 \%$. & $78-94 \%$ \\
\hline
\end{tabular}

\section{Potensi Tanaman Bengkuang erosus L.) Sebagai Pupuk Organik}

$(P$.

Bengkuang (Pachyrrhizuz spp.L.) adalah tanaman legum yang mempunyai potensi yang sangat baik digunakan dalam usaha untuk mencapai sistem pertanian berkelanjutan. Bengkuang mempunyai biomassa yang banyak dengan kandungan nitrogen di dalam biomassa bengkuang selain umbi cukup tinggi berkisar $3.42 \%-3.51 \%$ sehingga dapat digunakan sebagai pupuk organik/hijau. Seperti halnya famili Leguminosae yang lainnya, bengkuang mempunyai kemampuan untuk bersimbiosis dengan bakteri Rhizobium dan Bradyrhizobium dalam menambat nitrogen $\left(\mathrm{N}_{2}\right)$ udara. Sekitar $70-77 \%$ dari jumlah $\mathrm{N}$ dalam tanaman bengkuang berasal dari fiksasi (penambatan) $\mathrm{N}_{2}$ udara oleh bakteri Rhizobium dan Bradyrhizobium (Peoples dan Ceaswell,
1992; Castellanos et al., 1997). Setelah ditanami bengkuang, kebutuhan nitrogen untuk tanaman berikutnya dapat dikurangi bahkan dapat ditiadakan (Castellanos et al., 1997).

Uji coba yang pertama kali dilakukan oleh Castellanos et al., (1997) di lapangan mengenai jumlah $\mathrm{N}$ hasil fiksasi terhadap dua perlakuan dari brangkasan bengkuang (penunasan dan panen) setelah 154 hari hasilnya yaitu: $58-80 \mathrm{~kg}$ $\mathrm{N}$ ha $^{-1}\left(60-76 \mathrm{~g} \mathrm{~N} \mathrm{t}^{-1}\right.$ biomassa hari $\left.{ }^{-1}\right)$ untuk jenis $P$. ahipa, dan tiga jenis $P$. erosus (penunasan dan panen) setelah 154 - 168 hari yaitu: $162-215 \mathrm{~kg} \mathrm{~N} \mathrm{ha}^{-1}$ $\left(70-84 \mathrm{~g} \mathrm{~N} \mathrm{t}^{-1}\right.$ biomassa hari $\left.{ }^{-1}\right)$. Sekitar $50 \%$ dari pemanenan $\mathrm{N}$ yaitu $130 \mathrm{~kg} \mathrm{~N}$ ha 1 setara dengan $800 \mathrm{~kg}$ protein $\mathrm{ha}^{-1}(\mathrm{~N} \mathrm{x}$ 6.25) terakumulasi dalam umbi $P$. erosus. Hal ini menunjukkan bahwa jumlah penambatan nitrogen oleh Rhizobium yang bersimbiosis dengan bengkuang memiliki kemampuan simbiosis yang lebih tinggi dibandingkan dengan bila bersimbiosis dengan tanaman legum lainnya (Peoples dan Ceaswell, 1992).

Menurut Valiant dan Desfontaines (1995), tanaman bengkuang mampu beradaptasi dan memfiksasi $\mathrm{N}$ dalam berbagai kondisi iklim serta dapat tumbuh baik pada wilayah tropis basah. Disamping itu bengkuang juga dilaporkan bersimbiosis dengan cendawan mikoriza (AMF) yang dapat membantu penyerapan unsur hara terutama fosfor. Simbiosis dengan cendawan mikoriza ini sangat penting artinya untuk mendapatkan unsur 
hara guna menunjang pertumbuhan dan produksi yang memuaskan. Grum (1998) melaporkan bahwa inokulasi bengkuang dengan cendawan mikoriza seperti Glomus manihotiis dan Entrophospora colombiana sangat nyata meningkatkan pertumbuhan dan produksi bengkuang. Simbiosis bengkuang dengan mikoriza ini juga membuat bengkuang lebih tahan terhadap kekeringan (Diouf et al., 1998). Keberadaan rhizobium dan mikoriza tersebut dapat membantu meningkatkan ketersediaan unsur $\mathrm{N}$ dan $\mathrm{P}$ bagi tanaman serta dapat meningkatkan efisiensi pengambilan $\mathrm{N}$ dan $\mathrm{P}$ yang berasal dari pupuk anorganik sehingga jumlah pupuk anorganik yang diberikan dapat dikurangi.

Beberapa keistimewaan tanaman bengkuang antara lain: budidayanya tidak memerlukan keahlian dan alat yang spesifik, beradaptasi baik terhadap iklim dan tanah, penampilan hasil yang tinggi yaitu dapat mencapai 100 ton ha $^{-1}$ dalam masa tanam pendek sekitar $4-6$ bulan, toleran terhadap kekeringan, nilai nutrisi yang tinggi, dapat menambat nitrogen (biological nitrogen) serta memiliki sifat insektisida sehingga pupuk $\mathrm{N}$ dan insektisida yang diperlukan bisa lebih sedikit (Sorensen, 1994).

Hal yang lebih menarik lagi adalah bahwa tanpa penambahan pupuk buatan sama sekali, bengkuang mampu mencapai hasil yang tinggi di beberapa tempat di Mexico dan Pasifik Selatan (Nielson et al., 1998). Hal ini membuktikan bahwa kadar unsur hara pada biomassa bengkuang cukup tinggi. Hasil penelitian Adawiyah (2006) menunjukkan bahwa kandungan unsur $\mathrm{N}$, $P$, dan $K$ pada biomassa bengkuang cukup tinggi dan kandungan $\mathrm{N}$ biomassa bengkuang lebih tinggi dibandingkan dengan kandungan unsur tersebut pada beberapa jenis bahan dasar kompos hasil penelitian Suhardiyanto (1985) dan pupuk kandang (Hairiah, 1992 dalam Budianta, 1999) (Tabel 2).

Pupuk organik alamiah tidak hanya mengadung unsur hara makro, tetapi juga mengadung unsur hara mikro serta senyawa-senyawa organik seperti protein, asam-asam organik, hormon dan vitamin alami, dan enzim-enzim hasil dekomposisi bahan organik maupun aktivitas berbagai jenis mikroba yang hidup dalam bahan pupuk organik. Diketahui juga bahwa pupuk organik dapat mengurangi serangan hama karena meningkatnya jenis dan populasi predator maupun mikroba antagonis yang sangat bermanfaat bagi keberhasilan penerapan sistem pertanian organik (Culliney dan Pimentel, 1986; Edwards dan Stinner 1990; Eigenbrode dan Pimentel, 1988). 
Tabel 2. Kandungan Unsur Hara dalam Biomassa Bengkuang (Adawiyah, 2006), Beberapa Jenis Bahan Dasar Kompos (Suhardiyanto,1985) dan Pupuk Kandang (Hairiah, 1992 dalam Budianta, 1999)

\begin{tabular}{|c|c|c|c|}
\hline \multirow[b]{2}{*}{ Jenis } & $\mathrm{N}$ & $P$ & $\mathrm{~K}$ \\
\hline & \multicolumn{3}{|c|}{$(\%)$} \\
\hline Bengkuang & 3.79 & 0.17 & 1.05 \\
\hline Mucuna pruriens & 3.00 & 0.23 & 1.23 \\
\hline Vigna unguiculata & 3.20 & 0.22 & 0.43 \\
\hline $\begin{array}{l}\text { Psophocarpus } \\
\text { palustris }\end{array}$ & 2.80 & 0.26 & 0.92 \\
\hline $\begin{array}{l}\text { Pueraria } \\
\text { phaseoloides }\end{array}$ & 2.50 & 0.24 & 0.95 \\
\hline Arachis hipogea & 0.70 & 0.10 & 0.20 \\
\hline Jerami Padi & 0.60 & 0.10 & 0.20 \\
\hline Alang-alang & 0.40 & 0.10 & 0.10 \\
\hline Kotoran Domba & 0.99 & 0.36 & 0.85 \\
\hline Kotoran Sapi & 1.51 & 0.85 & 0.34 \\
\hline Kotoran Ayam & 0.98 & 1.19 & 1.16 \\
\hline
\end{tabular}

Dijelaskan pula oleh Evanylo (1996), De Ceuster dan Hoitink (1999) bahwa ketersedian unsur hara nitrogen yang berlebihan akibat pemberian pupuk kimia anorganik dosis tinggi justru menyebabkan tanaman mudah terserang penyakit layu Fusarium maupun Phytophthora, sebaliknya penyediaan unsur hara nitrogen secara bertahap melalui pemberian pupuk organik dapat mencegah terjadinya serangan penyakit layu tersebut. Apalagi pemberian pupuk organik juga dapat meningkatkan populasi Trichoderma spp., Gliocladium spp. dan Flavobacterium balustinum yang sangat bermanfaat sebagai antagonis penyakit atau berfungsi sebagai fungisida hayati.

Jenis tanaman yang banyak digunakan sebagai pupuk hijau adalah jenis tanaman legum (leguminosa) seperti bengkuang. Tanaman legum baik digunakan sebagai pupuk organik karena memiliki nisbah $\mathrm{C} / \mathrm{N}$ yang rendah jika dibandingkan dengan tanaman nonlegum dan pupuk kandang dengan nisbah $\mathrm{C} / \mathrm{N}$ yang jauh lebih tinggi, yang menyebabkan proses pendekomposisian lebih lama dan proses mineralisasi hara lebih lambat dari tanaman legum (Isrun, 2010). Hasil penelitian Adawiyah (2006) menunjukkan bahwa nisbah $\mathrm{C} / \mathrm{N}$ bengkuang sebesar 13.90 jauh lebih rendah dibandingkan dengan beberapa jenis tanaman dan pupuk kandang yang dilaporkan Sisworo (2000) (Tabel 3).

Dari segi kandungan unsur hara biomassa bengkuang yang cukup tinggi dan nisbah $\mathrm{C} / \mathrm{N}$ yang rendah, dapat diambil kesimpulan bahwa biomassa bengkuang memiliki potensi yang besar untuk dijadikan sebagai pupuk organik. Faktor yang penting dari tanaman untuk dijadikan pupuk organik adalah produksi biomassa yang banyak dan akumulasi $\mathrm{N}$. Tanaman bengkuang disamping menghasilkan biomassa yang dapat dijadikan pupuk organik juga menghasilkan umbi yang dapat dipasarkan dengan harga jual yang cukup tinggi dan umbi tersebut memiliki berbagai macam kegunaan. Kandungan kimia bengkuang yaitu pachyrhizon, rotenon, inulin (oligosakarida yang memberi rasa manis), vitamin B1 serta C. Umbi bengkuang memiliki kandungan gula, pati dan fosfor serta kalsium. Umbi ini juga mempunyai dampak pendingin karena memiliki kandungan air 86-90\%. 
Tabel 3. Kandungan Unsur $\mathrm{C}, \mathrm{N}$, dan Nilai Nisbah $\mathrm{C} / \mathrm{N}$ Bengkuang (Adawiyah, 2006), Beberapa Jenis Tanaman dan Pupuk Kandang (Sisworo, 2000)

\begin{tabular}{lccc}
\hline \multirow{2}{*}{ Jenis Bahan } & $\mathrm{C}$ & $\mathrm{N}$ & Nisbah \\
\cline { 2 - 4 } & $(\%)$ & $(\%)$ & $\mathrm{C} / \mathrm{N}$ \\
\hline Bengkuang & 52.68 & 3.79 & 13.90 \\
\hline $\begin{array}{l}\text { Brangkasan } \\
\text { Jagung }\end{array}$ & 49.42 & 1.17 & 42.24 \\
\hline Jerami Padi & 45.25 & 1.01 & 44.80 \\
\hline Tongkol Jagung & 51.66 & 0.72 & 76.77 \\
\hline Kotoran Domba & 26.33 & 0.99 & 26.26 \\
\hline Kotoran Ayam & 24.29 & 0.98 & 24.79 \\
\hline Kotoran Sapi & 47.36 & 1.51 & 31.36 \\
\hline
\end{tabular}

\section{Potensi Ekstrak Biji Bengkuang Sebagai Insektisida Nabati}

Penggunaan insektisida kimia sebagai pengendalian hama tanaman berpengaruh buruk terhadap lingkungan dan residu yang tertinggal dalam hasil panen dapat membahayakan ternak bahkan manusia. Beberapa pengaruh negatif yang akan timbul akibat penggunaan insektisida sintesik/kimia adalah dapat menyebabkan resistensi hama, peledakan hama sekunder, membunuh organisme non sasaran serta pencemaran lingkungan. Antisipasi terhadap dampak negatif penggunaan insektisida sintesik/kimia menjadi faktor utama yang diupayakan untuk mencari alternatif senyawa-senyawa insektisida yang tidak menimbulkan dampak negatif terhadap lingkungan, makhluk hidup lain dan mempunyai sifat yang mudah terurai sehingga tidak berbahaya serta mampu mengendalikan hama.

Tanaman sebenarnya kaya akan bahan aktif yang berfungsi sebagai alat pertahanan alami terhadap pengganggunya. Oleh karena itu perkembangan bahan aktif asal tanaman akhir-akhir ini mulai diteliti kembali pemanfaatannya. Pemanfaatan bagian tanaman sebagai insektisida nabati masih perlu diteliti potensi dan permasalahan pengembangannya. Oleh karena bahan insektisida yang berasal dari tanaman yang menggunakan bahan hasil metabolit sekunder tanaman sebagai bahan aktifnya akan menjamin keamanan bagi lingkungan karena cepat terurai di tanah serta tidak berbahaya terhadap ternak dan manusia. Salah satu tanaman yang memiliki potensi sebagai insektisida nabati berspektrum luas yang aman bagi lingkungan diantaranya adalah tanaman bengkuang terutama pada bijinya mengandung bahan aktif rotenon (Grainge dan Ahmed,1988).

\section{Toksisitas Tanaman Bengkuang}

Tanaman bengkuang sebenarnya sudah lama dimanfaatkan untuk insektisida dan racun ikan di daerahdaerah tropis, sedangkan penelitian secara khusus mengenai sifat insektisida tanaman bengkuang dan pengujiannya sudah dimulai oleh para ahli antara lain Liu dan Hsu di Cina (Hansberry dan Lee, 1942; Plank, 1944; dan Clausen dan Norton, 1945 dalam lbadurrahman, 1993).

Biji bengkuang giling dengan konsentrasi 4 lbs/gallon (452,6 g/454,6 I) sangat efisien sebagai insektisida untuk Phyllotreta vittata Fabricius (Coleoptera: Chrysomelidae), Myzus persicae Sulz. 
(Homoptera : Aphididae), dan Oregma lanigera Zehntner (Homoptera : Aphididae), (Liu dan Hsu dalam Ibadurrahman, 1993).

Perlakuan terhadap berbagai serangga yang diberi makan daun yang dilumuri tepung polong atau campuran biji dan polong bengkuang (polong digiling tersendiri atau bersama biji) menunjukkan bahwa polong tanaman bengkuang mempunyai toksisitas yang rendah sedangkan biji mempunyai toksisitas yang tinggi terhadap imago Cerotoma rificornis Forster (Coleoptera: Chrysomelidae), larva Diaphania hyalinata (L.), larva Laphygma frugiperda (A.\& S.) (Lepidoptera : Noctuidae), dan larva Plutella maculipennis Curtis (Lepidoptera : Plutellidae) (Tabel 4). Serangga tersebut diberi makan daun yang dilumuri tepung polong (polong digiling tersendiri) atau campuran biji dan polong bengkuang (polong digiling bersama biji).

Tabel 4. Toksisitas Bengkuang (P. erosus) (Plank dalam Ibadurrahman 1993)

\begin{tabular}{|c|c|c|c|c|}
\hline $\begin{array}{l}\text { Bagian } \\
\text { tanaman }\end{array}$ & $\begin{array}{l}\text { imago Cerotoma } \\
\text { rificornis }\end{array}$ & $\begin{array}{l}\text { larva Diaphania } \\
\text { hyalinata }\end{array}$ & $\begin{array}{l}\text { larva Laphygma } \\
\text { frugiperda }\end{array}$ & $\begin{array}{l}\text { Iarva Plutella } \\
\text { maculipennis }\end{array}$ \\
\hline \multicolumn{5}{|c|}{ P.erosus var. A.P.I. 88365} \\
\hline Polong & 0 & 4,2 & 0 & 4,0 \\
\hline $\begin{array}{l}\text { Biji : Polong } \\
(1: 1)\end{array}$ & 0 & 80,0 & 41,7 & 72,0 \\
\hline \multicolumn{5}{|c|}{ P.erosus var. C43-23 } \\
\hline Polong & 0 & 4,0 & 8,7 & 4,2 \\
\hline $\begin{array}{l}\text { Biji : Polong } \\
(1: 1)\end{array}$ & 0 & 84,0 & 40,0 & 56,5 \\
\hline \multicolumn{5}{|c|}{ P.erosus var. B. Of E \& P.Q.; Meksiko } \\
\hline Polong & 0 & 4,8 & 0 & - \\
\hline $\begin{array}{l}\text { Biji : Polong } \\
(1: 1)\end{array}$ & 0 & 92,5 & 76,0 & 69,6 \\
\hline
\end{tabular}

\section{Kandungan Senyawa Insektisida Bengkuang}

Walaupun umbi bengkuang dapat dimakan, bagian bengkuang yang lain seperti daun,batang, akar, polong masak dan terutama bijinya sangat beracun karena mengandung rotenon, sama seperti tuba. Racun ini sering dipakai untuk membunuh serangga atau menangkap ikan. Racun ini bisa dimanfaatkan untuk bahan pembuatan pestisida nabati dalam menunjang budidaya pertanian organik.
Tanaman bengkuang mengandung sekitar $0,1 \%$ rotenon dan toksin lain. Berdasarkan berat kering, kandungan rotenon pada batang sebesar 0,03\%, daun $0,11 \%$, polong $0,02 \%$, biji $0,66 \%$, sedangkan umbi tidak mengandung rotenon. Glikosida sianogenik ditemukan pada daun, kulit batang, dan akar bengkuang. Diketahui juga bahwa tanaman dari genus Pachyrrhizus mengandung dua saponin (Pachysapogenin A dan B) dan isolfavanon (Dehidroneotenon) (Duke, 1983). Hansberry dan Norton dalam 
Ibadurrahman (1993) mengisolasi rotenon dan enam senyawa baru dari ekstrak eter biji bengkuang asal Meksiko (Tabel 5). Ketika ketujuh senyawa tersebut diuji pada larva kumbang kacang Meksiko (Epilachna varivestis), hasilnya adalah terdapat empat dari senyawa tersebut yang tidak aktif, sedangkan rotenon dan senyawa 5 dan 7 (Tabel 5) aktif. Dengan kata lain rotenon dan dua senyawa lain yang terkandung dalam biji bengkuang ternyata bersifat aktif ketika diuji pada larva kumbang kacang (Epilachna varivestis). Sebagian besar senyawa yang diisolasi terbukti mempunyai kaitan dengan rotenoid karena mempunyai rumus empiris yang mirip (mengandung senyawa metoksil) dan tanggap terhadap uji warna rotenoid. Hasil peneltian dengan biji bengkuang asal Amerika juga membuktikan bahwa terdapat hubungan yang nyata antara toksisitas, kandungan resin dan kandungan rotenon. Meyer (dalam Ibadurrahman 1993) mengisolasi senyawa pachyrrhizon dari ekstrak eter biji bengkuang asal Indonesia dengan hasil bahwa senyawa yang diperoleh sama dengan senyawa 2 (Tabel 5). Pada kondisi lapangan, efektifitas bahan aktif tersebut dapat bertahan selama 2-3 hari (Graige dan Ahmed, 1988).

Tabel 4. Senyawa yang diisolasi dari biji bengkuang (Hansberry dan Norton dalam Ibadurrahman, 1993)

\begin{tabular}{ccccc}
\hline Senyawa & Rumus Empiris & Gugus $\mathrm{CH} 3 \mathrm{O}$ & Uji Durham & Persentase \\
\hline 1 & $\mathrm{C}_{9} \mathrm{H}_{4} \mathrm{O}_{3}$ & 0 & - & 0,1 \\
2 & $\mathrm{C}_{20} \mathrm{H}_{14} \mathrm{O}_{7}$ & 1 & + & 8,0 \\
3 & $\mathrm{C}_{20} \mathrm{H}_{12} \mathrm{O}_{6}$ & 1 & - & 7,0 \\
4 & $\mathrm{C}_{23} \mathrm{H}_{22} \mathrm{O}_{6}$ & 2 & + & 4,0 \\
(rotenon) & & & + & 0,3 \\
5 & $\mathrm{C}_{20} \mathrm{H}_{16} \mathrm{O}_{6}$ & 2 & - & 0,1 \\
6 & $\mathrm{C}_{20} \mathrm{H}_{12} \mathrm{O}_{6}$ & 1 & - & 7,0 \\
7 & $\mathrm{C}_{23} \mathrm{H}_{18} \mathrm{O}_{8}$ & 1 & & \\
(resin) & & &
\end{tabular}

Semua bagian tanaman bengkuang kecuali umbi mengandung rotenon. Kandungan kimia dalam daun (Gambar 1 a) dan biji bengkuang (Gambar 1 b) adalah rotenon. Biji bengkuang selain mengandung rotenone, juga mengandung pachyrrhizid, pachyrrhizine, saponin, dan lain-lain yang bekerja secara sinergis sebagai insektisida dan juga akarisida. Namun demikian yang banyak digunakan sebagai pestisida nabati adalah bijinya. 

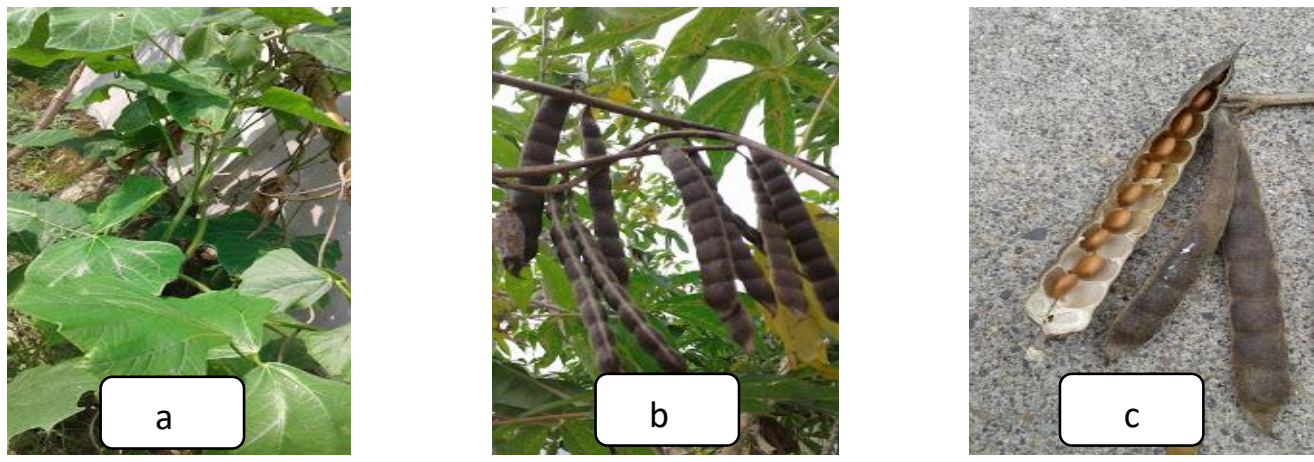

Gambar 1. Daun bengkuang (a); Polong bengkuang (b); dan Biji bengkuang (c)

Rotenon adalah racun pencernaan dan racun kontak, mekanisme kerjanya mengganggu respirasi sel, selain itu rotenon juga merupakan racun saraf. Cara kerja biji bengkuang sebagai insektisida adalah dengan cara menghambat metabolisme dan sistem syaraf, serta penghambat makan (antifeedant). Rotenon merupakan inhibitor kuat elektron transpor yaitu antara $\mathrm{NAD}^{+}$dengan koenzim $Q$, oksidasi suksinat dan sitokrom oksidase pada mitokondria (Krisna, 2002). Rotenon yang mempunyai sistem kerja sebagai racun kontak dan racun pencernaan terhadap beberapa larva serangga serta mempunyai sifat mudah terurai dalam sinar matahari dan udara terbuka (Oka, 1993). Insektisida nabati menunjukkan tingkat keamanan dan kesehatan yang lebih baik karena bahan aktif yang diperoleh dari tanaman tidak memiliki risiko dan efek samping di dalam penggunaannya sehingga aman untuk digunakan. Adapun organisme pengganggu tanaman (OPT) sasaran dari aplikasi rotenon adalah berbagai macam hama pengisap, kumbang dan ulat.
Pada tanaman hortikultura, OPT sasaran insektisida dari biji bengkuang adalah: Croccidolomia binotalis; Aphis fabae; A.craccivora; Bombix mori; Dysdercus megalopygus; Epilachna varivestis; Myzus persicae; Nezara viridula; Plutella xylostella; dan Spodoptera litura. Sementara untuk tanaman pangan dapat digunakan untuk melindungi benih tanaman dari serangan hama gudang. Serangga yang teracuni mati kelaparan yang disebabkan oleh kelumpuhan alat-alat mulut (Rizky, 2015).

Hasil penelitian Necha et al. (2004) menunjukkan bahwa senyawa rotenon yang terkandung dalam biji bengkuang berdaya racun tinggi untuk serangga hama, kutu-kutuan, dan ikan tetapi tidak untuk mamalia. Serangga yang teracuni akan mati kelaparan yang disebabkan oleh kelumpuhan alat-alat mulut dan selsel syaraf (Panji, 2009). Ekstrak biji bengkuang dalam mengendalikan ulat tanah yang termasuk hama penting pada tanaman tembakau sudah diteliti oleh Pramini (1998). Hasil penelitian tersebut menunjukkan bahwa ekstrak biji 
bengkuang nyata berpengaruh terhadap mortalitas dan aktivitas makan larva ulat tanah Agrotis sp. Dengan demikian berpotensi sebagai pengendali hama ulat tanah Agrotis sp. dengan cara aplikasi racun perut pada konsentrasi $20 \%$ dan racun kontak konsentrasi $40 \%$ (v/v). Dan ekstrak etanol biJi bengkuang efektif bersifat toksik terhadap ulat tanah pada konsentrasi 12,185\% (v/v) dengan cara aplikasi racun perut dan 26,210\% (v/v) dengan racun kontak. Disimpulkan bahwa efektivitas kerja insektisida dipengaruhi oleh beberapa faktor, antara lain jenis insektisida, jenis serangga dan level insektisida.

Perlakuan penggunaan ekstrak biji bengkuang dengan konsentrasi 8\% merupakan tingkat yang memiliki mortalitas tertinggi yaitu sekitar $8 \%$ dari total jumlah hidup awal, tingginya kematian yang diakibatkan oleh ekstrak biji bengkuang dimungkinkan adanya senyata aktif yang terkandung di dalam ekstrak biji bengkuang yaitu rotenon, yang dapat menyebabkan kematian pada serangga karena efek farmakologis dari rotenan adalah mencegah kemampuan Tribolium castaneum untuk menggunakan oksigen pada proses metabolisme.

Penelitian yang bertujuan mengetahui efektivitas biji bengkuang sebagai insektisida nabati terhadap larva lalat Crysomya bezziana (C. bezziana) agen penyebab miasis secara in vitro telah dilakukan. Penelitian terbagi menjadi 5 kelompok perlakuan. Masing-masing sebanyak 20 Larva instar 1 (L1), Larva instar 2 (L2), dan Larva instar 3 (L3) C.bezziana digunakan untuk pengujian in vitro menggunakan pot plastik yang berisi media larva dan ekstrak ethanol biji bengkuang dengan konsentrasi bertingkat $0,06,0,12$, dan $0,25 \%$. Coumaphos $0,06 \%$ dan akuades steril digunakan sebagai kontrol positif dan negatif. Hasil penelitian menunjukkan bahwa pada konsentrasi 0,25\% mampu menyebabkan 100\% kematian larva dan 100\% pupa tidak menetas. Pengujian L3 menunjukkan bahwa ekstrak ethanol biji bengkuang mampu menyebabkan penurunan daya tetas pada semua konsentrasi. Pengujiaan L1 dan L2 untuk mengindikasikan efektifitas ekstrak sebagai racun perut, sedangkan pengujian pada L3 sebagai indikasi racun kontak. Biji bengkuang memiliki daya larvasida terhadap beberapa jenis larva serangga $C$. Bezziana.

(https://www.researchgate.net/publication/ 322392214_Aktivitas_Larvasida_Biji_Ben gkuang_sebagai_Insektisida_Nabati_terha dap_Larva_Lalat_Crysomya_bezziana [2018].

\section{PENUTUP}

Tantangan produksi pertanian di masa yang akan datang tidak hanya tertumpu pada upaya peningkatan produksi pertanian, tetapi juga pada kelestarian lingkungan dan kesehatan masyarakat. Teknologi produksi yang dimasyarakatkan dan dilaksanakan oleh 
petani cenderung sangat boros energi dan berpengaruh negatif terhadap kelestarian kesuburan tanah, tanaman, manusia dan lingkungan. Hal ini sebagai akibat dari ketergantungan petani pada penggunaan pupuk anorganik dan pestisida sintetik/kimia.

Pemanfaatan pupuk organik untuk usaha pertanian akan mengurangi resiko pencemaran lingkungan, meningkatkan efisiensi pemupukan, serta menekan pengaruh negatif dari penggunaan pupuk anorganik. Hal ini berarti bahwa dengan pemanfaatan bahan organik akan mendukung program pertanian organik yang berkelanjutan dan berwawasan lingkungan. Sistem pertanian berkelanjutan dapat tercapai bila sistem tersebut secara ekologi tidak merusak, secara ekonomi menguntungkan dan secara sosial dapat diterima, sehingga secara teknologi, ekologi, ekonomi, dan sosial dapat berkelanjutan.

Peran legum seperti bengkuang (Pachyrrhizuz erosus L.) perlu dikaji lebih mendalam untuk meningkatkan kesuburan tanah dan memenuhi kebutuhan pupuk organik di dalam menjaga keseimbangan siklus hara, serta mengurangi penggunaan pestisida nabati. Tanaman bengkuang sangat potensial dalam mendukung diterapkannya sistem pertanian organik karena; biomassa yang banyak dan mengandung nitrogen yang tinggi (3.42\% - 3.51\%), kemampuan hidup yang sangat luas di berbagai kondisi lahan karena bersimbiosis dengan bakteri
Rhizobium dan Bradyrhizobium dalam menambat nitrogen $\left(\mathrm{N}_{2}\right)$ udara dan bersimbiosis dengan cendawan mikoriza (AMF) yang dapat membantu penyerapan unsur hara terutama fosfor. Selain itu, kecuali umbi, bagian tanaman lainnya terutama pada biji bengkuang mengandung metabolit sekunder seperti rotenon yang bersifat insektisida. Dengan demikian maka bengkuang ini dapat dimanfaatkan sebagai bahan pupuk organik dan sebagai insektisida nabati dalam mendukung sistem pertanian organik.

Antisipasi terhadap dampak negatif penggunaan insektisida sintesik/kimia menjadi faktor utama yang diupayakan untuk mencari alternatif senyawa-senyawa insektisida yang tidak menimbulkan dampak negatif terhadap lingkungan, makhluk hidup lain dan mempunyai sifat yang mudah terurai sehingga tidak berbahaya serta mampu mengendalikan hama.

Rotenon adalah racun pencernaan dan racun kontak, mekanisme kerjanya mengganggu respirasi sel, selain itu rotenon juga merupakan racun saraf. Cara kerja biji bengkuang sebagai insektisida adalah dengan cara menghambat metabolisme dan sistem syaraf, serta penghambat makan (antifeedant). Adapun organisme pengganggu tanaman (OPT) sasarannya adalah berbagai macam hama pengisap, kumbang dan ulat. 


\section{DAFTAR PUSTAKA}

Adawiyah, R. 2006. Penanaman bengkuang dan sentro dalam meningkatkan kesuburan tanah dan ketersediaan pupuk hijau. Majalah BERSAMA: Vol. 10 No.1 Januari- juni 2006. Hal 94-101.

Arevalo T, A. (1998). Effect of flower removal on the yield of root tubers of Pachyrhizus erosus (L.) Urban. [Spanish]. In: Sørensen, M., J.E. Estrella, O.J. Hamann, and S.A. Rios Ruiz (eds.), Proceedings of the 2nd international symposium on tuberous legumes, Celaya, Guanajuato, Mexico 5-8 August 1996, pp. 115-124.

Copenhagen, Denmark Grainge, M., S. Ahmed, W.C. Mitchell, dan J.W. Hylin. 1985. Plant species reportedly possessing pest control proporties. An $\mathrm{EWC} / \mathrm{UH} \quad$ Database, Resources System. Institut E.W. Center, Univ. Of Hawaii, Honolulu. 249 hal.

Castellanos, J.Z., F. Zapata, V. Badillo, J.J. Pena-Cabriales, E.S. Jensen, and E.Heredia-Garcia. (1996). Symbiotic nitrogen fixation and yield of Pachyrhizus erosus L. Urban cultivars and Pachyrhizus ahipa (Wedd) Parodi landraces as affected by flower pruning. Soil Biology and Biochemistry 29: 973-981.

Chooi, O. H. 2008. Vegetables for Health and Healing. Utusan Publications \& Distributors Sdn Bhd, Kuala Lumpur.

Culliney, T.W. and Pimentel, D., 1986, Ecological Effects of Organic Agricultural Practices on Insect Populations. Agric. Ecosyst. Environ. 15:253-256.

de Ceuster, T.J.J. and Hoitink, H.A.J., 1999, Using Compost To Control Plant Diseases, Evaluate The Prospects for
Composts and Biocontrol Agents to Replace Methyl Bromide to Protect Plants, BioCycle Magazine, June, $p$. 61

de Melo, E.P., N. Krieger, and T.L.M. Stamford.

1994.Physchochemical

properties of Jacatupe

(Pachyrhizus erosus L. Urban) starch. Starch 46: 245-247.

Diouf, O.,M. H. Roy-McCauley, and D.J.M. Anne Rose. (1998). Tuber-pod competition and drought responses in Yam Bean (Pachyrhizus ahipa (Wedd.) Parodi). In: Sørensen, M., J.E. Estrella, O.J. Hamann and S.A. Rios Ruiz (eds.), Proceedings of the 2nd international symposium on tuberous legumes, Celaya, Guanajuato, Mexico 5-8 August 1996, pp. 407-412. Copenhagen, Denmark.

Faradita. 2010. Evektivitas Penggunaan Ekstrak Biji Bengkuang (Pachyrrizus erosus) terhadap Mortalitas Ulat Plutella xylostella pada Tanaman Kubis. Program Kreativitas Mahasiswa.

Grainge, M., dan S. Ahmed, 1988. Handbook of Plants with Pest Control Properties. John Wiley \& Sons. New York. $470 \mathrm{hlm}$.

Grüneberg, W.J., F. Leopold, and D. Vasques. (2003). A new yam bean (Pachyrhizus spp .) interspecific hybrid. Genetic Resources and Crop Evolution 50:757-766.

Grum, M. (1994). Breeding of new yam bean ( Pachyrhizus Rich. ex DC.) cultivars in Tonga involving interspecific hybrids. In : Sørensen, M. (Ed.). Proceedings of the $1 \mathrm{st}$ international symposium on tuberous legumes, Guadeloupe, F.W.I., 2124 April 1992. Denmark.

Grum, M., O. Stölen, M. Halafihi, and M. Sørensen. (1994). Genotypic 
and environmental variation in response to inflorescence pruning in Pachyrrhizus erosus L. Urban. Experimental Agriculture. Pp. 11

Hoogenboom, G., M.G. Huck, C.M. Peterson. (1987). Root growth rate of soybean as affected by drought stress. Agron. J. 79:607-614.

Ibadurrahman. 1993. Daya racun bubuk biji bengkuang (Pachyrhizus erozus L.) Urban) terhadap Callosobruchus maculatus (F.) (Coleoptera: Brucidae). Skripsi. Jurusan Hama dan Penyakit Tumbuhan Fakultas Pertanian, IPB.

Johnson, F.A. and G.S. Nuessly. 1994. Whiteflies. In L.G. Higley and D.J. Boethel (eds). Handbook of Soybean Insect Pest. p: 9799. USA: The Entomological Society of America, 9301 Annapolis Road, Lanham MD 20706-3115.

Kale, P. R. (2006). Studies on nutritional and processing properties of storage roots of different yam bean (Pachyrhizus spp.) and Wild Mung Bean (Vigna vexillata) Species. PhD Dissertation. Cuvillier Verlag Göttingen Germany, ISBN: 3865377866. pages 132.

Kardinan, A. 1999. Pestisida nabati ramuan dan aplikasi. Jakarta: Penebar Swadaya.

Kardinan, A. dan A. Dhalimi. 2003. Mimba (Azadirachta indica A. Juss) tanaman multi manfaat. Perkembangan Teknologi TRO. Vol Xv (1): 1-10.

Karuniawan, A. (2004). Cultivation status and genetic diversity of yam bean (Pachyrhizus erosus (L). Urban) in Indonesia. Cuvillier Verlag Gottingen, Germany.

Karuniawan, A., and N. Wicaksana. (2006). Genetic relationships of yam bean (Pachyrhizus erosus) population based on morphological characters of flowers and leaves.
[Indonesia]. Buletin Agronomi IPB. Vol. XXXIV No. 2: 98-105

Karuniawan, A dan S. Nusifera. 2009. Respon Tanaman bengkuang terhadap pemangkasan reproduktif untuk karakter hasil dan kualitas ubi. Skripsi Fakultas Pertanian Universitas Pajajaran, Bandung.

Krisna S. L. S., Eka. 2002. Studi Pengaruh Ekstrak Biji Bengkuang (Pachyrhizus erosus) terhadap Perkembangan Larva Nyamuk (Aedes aegypti).Skripsi. Fakultas kedokteran Hewan. Institut Pertanian Bogor. Bogor.

Lingga, L. 2010. Cerdas Memilih Sayuran. PT Agro Media Pustaka, Jakarta.

Lukitaningsih, E. (2009). The Exploration of Whitening And Sun Screening Compounds in Bengkoang Roots (Pachyrhizus Erosus).

Matsumura, F. 1975. Toxicology of Pesticides. New York: Plenum Perss.

Martono, B., E. Hadipoentyanti, dan L. Udar no. 2004. Plasma nutfah insektisida nabati. Perkembangan Teknologi TRO Vol. XVI. No. 1. p:43-59.

Mau,R.F.L dan Keesing J.ML. 2007. Bemisia tabaci (Gennadius). Department of Entomology. Honolulu. Hawai. J.M. Diez (eds).

Necha, L. L. B., S. B Banos, L. B. Luna, F. J.L. G. Suarez, D. A. Solano and R. R. Chilpa. 2004. Antifungal activity of seed powders, extracts, and secondary metabolites of Pachyrhizus erosus (L.) Urban (Fabaceae) against three post harvest fungi. Revista Mexicena de Fitopatologia Vol 22 (003): 356-361.

Nielsen, P.E. and M. Sørensen. (1998). Reproductive prunning in Pachyrhizus ahipa (Wedd.) Parodi. In : Sørensen, M., J.E. Estrella, O.J. Hamann, and S.A. Rios Ruiz (Eds.). 
Proceedings of the 2nd international symposium on tuberous legumes, Celaya, Guanajuato, Mexico $5-8$ August 1996. Copenhagen, Denmark.

Nugroho, B., W. Dadang, dan D. Prijono. 1999. Bahan pelatihan pengembangan dan pemanfaatan insektisida alami. Pusat Kajian PHT. Bogor: IPB. $90 \mathrm{hlm}$.

Nurhakim, A., R. Wiradimadja dan I. Hernaman. 2013. Pengaruh penggunaan eketrak biji begkuang terhadap jumlah hidup Tribolium castaneum dan susut berat dedak padi dalam penyimpanan. Fakultas Peternakan Universitas Padjadjaran.

Oka, I. M. 1993. Penggunaan, Permasalahan serta Prospek Pestisida Nabati dalam Pengendalian Hama Terpadu. Prosding Seminar Hasil Penelitian Tanaman Rempah dan Obat. Bogor.

Panji, 2009. Pestisida Nabati. Bandung. http://blog_panji/pestisida. diakses 3 Oktober 2011.

Parakkasi, A. 1988. Ilmu Nutrisi dan Makanan Ternak Ruminan. University Indonesia Press, Bogor.

Parmini, W. 1998. Pengaruh ekstrak biji bengkoang (Pachyrrhizus erosus urb) terhadap mortalitas dan aktivitas makan ulat tanah (Agrotis sp). Undergraduate thesis, FMIPA UNDIP. Semarang.

Peter, K. V. 2008. Underutilized and Underexploited Horticultural Crops, Volume 4. New India Publishing Agency, New Delhi.

Schmutterer, H. 1990. Properties and potential of natural pesticides from neem tree, Azadirachta indica. Ann. Rev. Entomol. 35: 271-295.

Sørensen, M. (1996). Promoting the conservation and use of neglected crops 2: yam bean Pachyrhizus DC. International Plant Genetic Resources Institute, Italy.

Sorensen, M. 1998. Yam Bean Pachyrizus DC. International Plant Genetic Resources Institute. Italy.

Sudjito, B. 2009. Kebijakan Hukum Normatif Pengembangan Produk Industri berbasis tembakau (Nicotiana tabaccum) sebagai bahan pestisida Nabati yang berwawasan lingkungan. Universitas Brawijaya Malang. $9 \mathrm{hlm}$.

Vaughan, J. G. and Geissler, C. A. 2009. The New Oxford Book of Food Plants. Oxford University Press Inc, New York.

Y. A. Fitri. 2013. Ekstrak Bengkuang, Pestisida Nabati untuk Mengendalikan Spodoptera litura.

Ditjenbun.pertanian.go.id

Wahyuningsih, P. 1998. Pengaruh Ekstrak Biji Bengkuang (Pachyrrihzus erosus) terhadap

Mortalitas dan Aktivitas Makan Ulat Tanah (Agrotis sp). Jurusan Biologi, Fakultas Matematika Dan IImu Pengetahuan Alam, Universitas Diponegoro, Semarang.

Winarto, D. 2009. Memajukan Bengkuang Prembun. Harian Suara Merdeka. http://wikipedia. Suara Harian Merdeka. Diakses Tanggal 5 Juli 2018. 